\title{
Faculty Attitudes for Changing a University's Core and Structure
}

\author{
Kevin S. Krug ${ }^{1}$, Kole W. Dickson ${ }^{1}$, Julie A. Lessiter ${ }^{1} \&$ John S. Vassar ${ }^{1}$ \\ ${ }^{1}$ Louisiana State University Shreveport, USA \\ Correspondence: Kevin S. Krug, Ph.D., Department of Psychology, Louisiana State University Shreveport, 1 \\ University Place, Shreveport, LA 71115-2399, USA \\ Received: January 21, 2016 \\ Accepted: February 9, 2016 \\ Online Published: March 1, 2016 \\ doi:10.5430/ijhe.v5n2p63 \\ URL: http://dx.doi.org/10.5430/ijhe.v5n2p63
}

\begin{abstract}
America's universities and colleges are examining additional ways to raise student enrollment following government reductions in educational funding. Faculty were surveyed regarding their opinions of an administrative proposal to change the status of their commuter university, a school without any on-campus student housing, from teaching traditional semester length courses to predominately online and compressed courses. Results indicated that although younger faculty were willing to teach lower level courses online, most faculty members were resistant to teaching upper level online and compressed courses. Moreover, associate professors agreed teaching compressed courses would make it more difficult both to recruit new faculty and pursue promotion.
\end{abstract}

Keywords: Faculty Attitudes, Online, Compressed Courses, University, Teaching

\section{Introduction}

With the exception of two states, government funding for higher education has decreased on an average of $23 \%$ per student since the recession of 2009 (Mitchell, Palacios, \& Leachman, 2014). Moreover, Arizona, Louisiana, and South Carolina have continued to cut higher education funding even further, on the order of up to $40 \%$ (Mitchell et al., 2014). In order to return higher education to pre-recessional funding levels, governments must either make drastic cuts to other programs or raise taxes.

Colleges and universities are attempting to adjust to the new reality of government educational funding in several ways. First, reduce costs by cutting faculty positions, eliminating traditionally low enrollment majors, closing satellite campuses, and decreasing other university services such as library holdings and access to journal databases. For example, Arizona's university system has eliminated 2,100 positions, consolidated numerous programs, and closed eight distance learning campuses (Arizona Board of Regents, 2011). Second, increase course tuition and student fees. While on average, tuition costs have risen $26 \%$ since 2009, universities run the risk of student enrollment decreasing due to the rising costs of attending classes (Mitchell et al., 2014). Third, modify course delivery to offer degrees online, where course material is taught using the Internet, or a compressed teaching schedule with students learning the same material covered during a traditional semester, but within a shorter time span, sometimes on the order of a month. During such instances, students only take 1 or 2 courses at a time and spend anywhere from $3-5$ hours every day in the classroom.

\subsection{Background on Faculty Attitudes of Online and Compressed Teaching}

The literature detailing student attitudes and scholastic performances under online and compressed teaching schedules is extensive (for reviews, see Daniel, 2000; Davies, 2006; Scott \& Conrad, 1992). What is limited in scope, however, is the research examining the attitudes of faculty members towards online and compressed college teaching. One may argue faculty attitudes and perspectives are just as critical as those are of the students. Research has consistently shown that students will lose interest and view online and compressed course learning as ineffective if their teachers openly state the only true way to teach college material is face-to-face in a traditional semester classroom (Brett, 1996; Scott, 1995; Scott \& Conrad, 1992; Seamon, 2004).

During the last 20 years, online learning is gaining popularity across college and university campuses with close to $32 \%$ of all students having reported taking at least one Internet course (Allen \& Seamon, 2013). When teaching online, faculty members use the Internet to post lectures, assign readings, hold discussions, and test student knowledge. Feasibly, students enrolled in these classes may never have to enter a physical classroom but will still be granted credit and, ultimately, degrees. 
Some faculty continue to raise doubts about online learning partly because some employers do not think it is appropriate learning (Allen \& Seamon, 2013; Feldhaus \& Fox, 2004; Maki \& Maki, 2002; Stewart, Bachman, \& Johnson, 2010). This may have led to the misconception that degrees earned online are not as prestigious as traditional degrees, although research indicates both degree types are compatible in terms of material taught and learned (Daniel, 2000; Feldhaus \& Fox, 2004). In addition, other concerns center on the possibility of students cheating during exams, limited computer support from universities, lacking personal technological knowledge, and the amount of time necessary to prepare these courses (Stewart et al., 2010; Ulmer, Watson, \& Derby, 2007). A number of measures, such as requiring online students to take the exams with test monitors and universities providing additional support for the faculty teaching online, are helpful.

There are some studies examining how faculty view compressed courses (Brett, 1996; Daniel, 2000; Kretovics, Crowe, \& Hyun, 2005; Scott, 1996; Scott et al., 1992; Wilcoxson, 1998). One common criticism is the difficulty of covering all of the course material in a shorter time period (Allen, Miller, Fisher, \& Moriarty, 1982; Daniel, 2000; Friedman, 1980; Kretovics et al., 2005). As a result, faculty will change course formats and their teaching methods. Common examples include decreasing the amount of time lecturing in favor of additional in-class discussion time, small group projects, and off campus activities as well as relying more on text book guidance and term papers (Allen et al., 1982, Scott et al., 1992). Kretovics et al., (2005), found that male faculty teaching summer school were more likely to change writing assignments than their female colleagues. Furthermore, tenured faculty, associate and full, modified their teaching procedures more often than instructors and assistant professors (Kretovics et al., 2005). Fatigue from teaching compressed courses and not having enough time to adjust course content or direction based on immediate student feedback tended to be sources of other faculty complaints (Seamon, 2004; Scott et al., 1992).

Conversely, faculty know the benefits of teaching compressed courses. First, there is mention in the research literature, but with mixed results, that university enrollment can increase because nontraditional and part-time students prefer compressed courses (Daniel, 2000; Davies, 2006; Scott et al., 1992: Seamon, 2004). Second, compressed courses tend to have fewer student withdrawals (Seamon, 2004). Third, if a faculty member fulfills his or her lecture obligations early in the year by teaching extra compressed courses, the remaining time can be used to conduct research or fulfill university and community service obligations.

\subsection{Study Description and Objectives}

The Louisiana State University Shreveport (LSUS) is a commuter university, or a school without any on-campus student housing, that serves Northwestern Louisiana. The Shreveport-Bossier area has a population of 260,000 people and LSUS has about 181 faculty members with 2,500 undergraduate and 1,500 graduate students. Since 2009, LSUS, has experienced a series of government budget cuts totaling 58\%. In order to raise additional revenue, LSUS's administration has explored a number of options and proposed to the faculty that all courses should be taught either online or during 8 -week semester terms. With an online format, LSUS would be able to reach students outside the immediate geographical vicinity (Dobbs, Ward, \& del Carmen, 2009; Li \& Irby, 2008). Second, people living in the region but unable to attend traditional courses for an entire semester due to family or job circumstances may be more likely to enroll in compressed courses (Dobbs, Ward, \& del Carmen, 2009; Li \& Irby, 2008). While LSUS has noted new students are indeed enrolling in its online MBA program, the compressed courses have not netted any additional student enrollment.

While most colleges and universities have been offering online courses and degrees for the last ten years, a few, including Colorado College, Cornell College in Iowa, and the University of Wisconsin at Oshkosh, have been following the 8-week semester format for a number of decades, but this may not have always been intended to increase student enrollment. Colorado College uses a block teaching plan ( 1 or 2 classes per month) and has noticed an increase in student applications since it first instituted the program during the 1970's. Colorado College, however, introduced block teaching as a way to celebrate its centennial celebration and continues to use an enrollment cap on student admissions. Cornell College in Iowa during the fall semester of 2012 voted to change the academic year from 9 to 8 semesters. This offered the college the advantages of attracting more students by having additional class options each term while giving faculty members and students extra time to pursue summer research and service projects. Finally, the University of Wisconsin at Oshkosh has been offering courses via a block format since the 1970's, but experienced enrollment stagnation 20 years later. Since 2000, the university was able to increase its student enrollment drastically by offering new certifications, majors, and graduate degrees as well as becoming more appealing in other ways to minority, military veterans, and nontraditional students.

Past work has surveyed faculty attitudes of teaching online and compressed college courses, but literature gaps persist. First, there is little mention if faculty will support an administrative or top-down decision to change the delivery of course material from a traditional semester format to only online or compressed teaching. Second, while 
Kretovics et al., (2005) and Ulmer et al., (2007) conducted similar research, both had return rates less than 30\%. In addition, Stewart et al., (2010) never directly specified the total number of surveys sent out. Third, if faculty disapprove of additional online and compressed teaching, there appears nothing regarding which other alternatives they would want their universities to use to increase student enrollment. Finally, detailed analyses of faculty attitudes appear limited. Most research often discusses faculty demographics as made up of separate or independent variables, but interactions among these variables may exist. For example, would an assistant professor in the School of Mathematics and Sciences be less accepting of teaching online and compressed courses than an adjunct from the School of Business?

Based on these literature gaps, the authors have three hypotheses. Regarding our first hypothesis, if given the choice, faculty will probably not support an abrupt or complete transition to either an online or compressed course campus, however, they may agree to a combination of these teaching methods for some of the general educational requirements and lower level major courses. The second hypothesis sates that assistant and associate professors would be less likely, than adjuncts, instructors, and full professors, to want to teach online and compressed courses. Our third hypothesis is that the faculty will agree that most of LSUS's students will be unable to maintain successfully a curriculum of only online or compressed courses during their entire college careers.

\section{Method}

\subsection{Sample}

Of the 181 surveys sent out, 112 LSUS faculty members (Female, $n=51$, Male, $n=55$, Blank, $n=6$ ) responded or a rate of $61 \%$. Survey participation was voluntary. Table 1 lists the additional LSUS faculty demographics.

Table 1. Demographic characteristics of faculty participants $(\mathrm{N}=118)$

\begin{tabular}{llll}
\hline & Characteristic & $\mathrm{n}$ & $\%$ \\
\hline Age & & & \\
& & 6 & 5.8 \\
& $36-35$ & 27 & 22.8 \\
& $47-57$ & 28 & 23.7 \\
& 58 and over & 50 & 42.3 \\
& Blank & 3 & 2.5
\end{tabular}

Rank

$\begin{array}{lrl}\text { Adjunct } & 16 & 13.5 \\ \text { Instructor } & 16 & 13.5 \\ \text { Assistant } & 9 & 7.6 \\ \text { Associate } & 30 & 25.4 \\ \text { Full } & 36 & 30.5 \\ \text { Blank } & 5 & 4.2\end{array}$

Years Taught at LSUS

$0-5$

6-11

$12-17$

$18-24$

25 and over

Blank

$\begin{array}{rl}17 & 16.1 \\ 34 & 28.8 \\ 16 & 13.5 \\ 18 & 15.2 \\ 23 & 19.4 \\ 4 & 3.3\end{array}$

School

$\begin{array}{lrr}\text { Business } & 19 & 16.1 \\ \text { Education } & 20 & 16.9 \\ \text { Human Sciences } & 13 & 11.0 \\ \text { Humanities and Social Sciences } & 32 & 27.1 \\ \text { Mathematics and Sciences } & 21 & 17.7 \\ \text { Blank } & 7 & 5.9\end{array}$


Faculty members were surveyed based on the membership variables of age, academic rank, years at LSUS, and the schools where they teach.

\subsection{Materials}

The survey, listed in the appendix, was a 14 item forced choice questionnaire assessing the faculty perceptions of online and compressed university courses. In addition, faculty could choose up to five suggestions from a list of possible programs and initiatives, table 2, they would most want LSUS to use to increase student enrollment. Faculty were not instructed to rank order their choices.

Table 2. Faculty Preferences for Increasing Student Enrollment

\section{Partnerships with local companies $\mathrm{n}=54$}

Increase local and regional advertisements $\mathrm{n}=54$

New graduate programs $n=49$

Academic partnerships with local high schools $n=40$

Additional majors and programs offered on campus $n=39$

Strategic recruitment planning (men, minorities, international, and veterans) $n=37$

Establish a consortium of local and regional high schools and universities $\mathrm{n}=34$

Majors and programs offered at Barksdale Air Force base $n=33$

Class and degree program partnership with Centenary college $n=32$

Increase website and technology use in recruiting $\mathrm{n}=28$

Certification programs $n=24$

Policy where students need departmental permission to take $18+$ hours per semester $n=22$

Special transition programs for high risk transfer students $n=21$

Alternative energy sources on campus to save money on utilities $n=18$

Programs connected to federal veteran's programs $n=15$

Getting out financial award letters earlier $n=15$

Hiring consultants to make us more student friendly and appealing $\mathrm{n}=10$

New residence halls on campus $\mathrm{n}=1$

Upgrading campus buildings $\mathrm{n}=1$

Making friends with local business leaders $n=1$

Table 2 lists the recommendations the faculty would like for LSUS to pursue to increase student enrollment.

\subsection{Procedure}

During the fall semester of 2013, members of a Faculty Senate committee designed the survey with input from the University's Vice Chancellor for Academic Affairs. Once the questions were agreed to by both involved parties, the survey was presented to the Faculty Senate where there was majority vote to accept and administer it. After IRB approval, the Vice Chancellor sent an e-mail to each departmental chairperson. The e-mail explained the purpose of the survey was to assess faculty attitudes of online and compressed teaching.

Paper surveys were numbered and delivered, during the same semester or fall, 2013, to each department by the Vice Chancellor's office staff, through the campus mail system. As indicated by the Vice Chancellor's e-mail, prior to administering the surveys, the departmental chairs shuffled the surveys to preserve confidentiality. After completion, the department chairs collected the surveys and returned them to the lead author for data entry and analyses.

\subsection{Data Analysis}

Unless stated otherwise, an alpha level of $\mathrm{p} \leq .05$ was adopted throughout the analyses. Bonferroni adjustment tests were performed only for the $t$ test variables. If a $t$ score was reported, Bonferroni validated the $p$ value as significant or not.

\section{Results}

Analyses were conducted for each survey question to determine if any differences existed among the four faculty demographic category variables listed previously in table 1 . Of the 14 original survey questions, about half were significant. Other questions had $\mathrm{p}$ values close to significant, ranging from .06 to .07. Tables 3-5 list only the survey items that were significant or close to significant. 
As shown in table 3, only two of the survey's questions were significant or close to significant for age. Younger faculty supported teaching 100 and 200 level elective courses online more than the oldest group of faculty. Next, the youngest faculty group began to respond to the question asking if there was any interest in teaching 100 and 200 level elective compressed courses more than the other age groups, but this item was only close to significant. No faculty age differences were found for teaching $300,400,600$, and 700 online or compressed courses.

Table 3. Significant survey items for faculty age

\begin{tabular}{|c|c|c|c|c|c|c|}
\hline Item & $\underline{\text { Age }}$ & $\underline{\mathrm{M}}$ & $\underline{\mathrm{SD}}$ & $\underline{\mathrm{N}}$ & $\underline{F}$ & $\underline{\text { P-value }}$ \\
\hline 1. I would be interested in teaching & $25-35$ & 1.33 & .51 & 6 & 4.69 & $\leq .05$ \\
\hline \multirow{3}{*}{$\begin{array}{l}\text { LSUS's } 100 \text { and } 200 \text { level } \\
\text { elective classes online. }\end{array}$} & 58 and over & 3.50 & 1.56 & 50 & & \\
\hline & $36-46$ & 2.51 & 1.62 & 27 & 4.69 & .054 \\
\hline & 58 and over & 3.50 & 1.56 & 50 & & \\
\hline $\begin{array}{l}\text { 6. I think it will be good if I could } \\
\text { teach } 100 \text { and } 200 \text { elective } \\
\text { classes during an } 8 \text {-week } \\
\text { semester session. }\end{array}$ & $25-35$ & 1.83 & .75 & 6 & 2.32 & .07 \\
\hline
\end{tabular}

As displayed in table 3, survey questions 1 and 6 were the only significant items for faculty age.

The results of the faculty rank and school demographic variables, shown in tables 4 and 5, had only six significant or close to significant questions. Years of teaching at LSUS, as an independent variable, did not produce any significant items. First, associate professors were more likely than instructors to agree that if the 8-week semester is accepted, it will be both more difficult to attract new faculty to LSUS as well as fulfill the necessary research and service obligations for promotion to full professor. In addition, associate professors also agreed more than adjuncts and instructors that the average LSUS student will have difficulty maintaining the academic pace of an 8-week semester. Had the survey return rate been higher, this particular item may have been significant. Next, the faculty school variable was credited with four significant or close to significant survey items. Faculty members from both the Schools of Human Science and Humanities and Social Sciences thought more courses should be offered during the weekends as well in the months of January, May, or August than the faculty from the School of Business. One conflicting finding, however, was that while faculty from the School of Human Sciences thought the academic rigors of an 8-week semester will be difficult for most of the students than faculty from the School of Humanities and Social Sciences, both faculty groups supported month long courses. Perhaps, Human Sciences faculty think students are capable of succeeding in a month long class only if it is taken once or twice a year instead of full time. In addition, Humanities and Social Sciences faculty stated they would support teaching 300, 400, 600, and 700 level courses during an 8-week semester more than Human Sciences faculty. Finally, all faculty, regardless of school, agreed that LSUS should continue to offer at least one or two class sections of each course in the traditional face-to-face setting, $\mathrm{F}(4,99)=2.275, \mathrm{p}=.06$. 
Table 4. Significant survey items for faculty rank

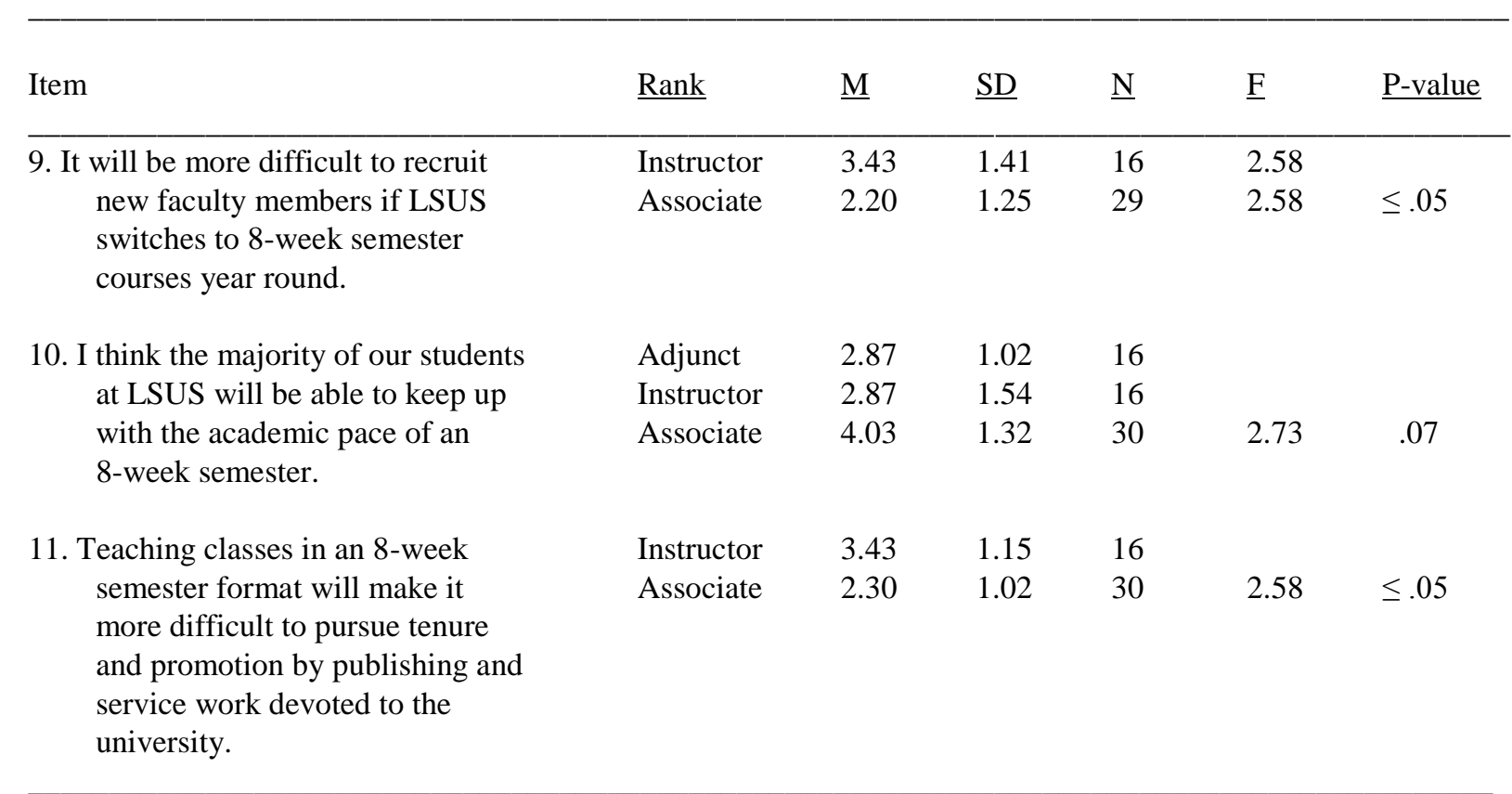

Table 4 demonstrates associate faculty members agreed more than instructors and adjuncts that an 8-week semester would make it more difficult to recruit new faculty members, be too quick of an academic pace for most of LSUS's students, and lengthen the process of earning the academic rank of full professor.

Table 5. Significant survey items for faculty school

\begin{tabular}{|c|c|c|c|c|c|c|}
\hline Item & $\underline{\text { School }}$ & $\underline{\mathrm{M}}$ & $\underline{\mathrm{SD}}$ & $\underline{N}$ & $\underline{F}$ & $\underline{\mathrm{P} \text {-value }}$ \\
\hline $\begin{array}{l}\text { 5. I would like for LSUS to offer } \\
\text { courses during weekends and } \\
\text { the months of January, May, } \\
\text { or August. }\end{array}$ & $\begin{array}{l}\text { Human Sci.* } \\
\text { Hum/Social** } \\
\text { Business }\end{array}$ & $\begin{array}{l}2.07 \\
2.61 \\
3.94\end{array}$ & $\begin{array}{r}.95 \\
1.20 \\
1.47\end{array}$ & $\begin{array}{l}13 \\
31 \\
19\end{array}$ & $\begin{array}{l}5.05 \\
5.05\end{array}$ & $\begin{array}{l}\leq .05 \\
\leq .05\end{array}$ \\
\hline $\begin{array}{l}\text { 7. I would support teaching } 300,400 \text {, } \\
600 \text {, or } 700 \text { classes at LSUS } \\
\text { during an } 8 \text {-week semester } \\
\text { session. }\end{array}$ & $\begin{array}{l}\text { Human Sci* } \\
\text { Hum/Social** }\end{array}$ & $\begin{array}{l}3.84 \\
2.50\end{array}$ & $\begin{array}{l}1.14 \\
1.52\end{array}$ & $\begin{array}{l}13 \\
32\end{array}$ & 2.29 & .06 \\
\hline $\begin{array}{l}\text { 10. I think the majority of our students } \\
\text { at LSUS will be able to keep up } \\
\text { with the academic pace of an } \\
\text { 8-week semester. }\end{array}$ & $\begin{array}{l}\text { Human Sci.* } \\
\text { Hum/Social** }\end{array}$ & $\begin{array}{l}4.38 \\
2.93\end{array}$ & $\begin{array}{l}.96 \\
1.50\end{array}$ & $\begin{array}{l}13 \\
32\end{array}$ & 2.42 & .053 \\
\hline
\end{tabular}

\footnotetext{
*School of Human Sciences

**S School of Humanities and Social Sciences
}

In table 5, faculty from both the schools Human Sciences and Humanities and Social Sciences supported teaching minimester or month long classes as well as upper level junior, senior, and graduate compressed courses. Only faculty members from school of Humanities and Social Sciences were confident the majority of LSUS's students could successfully maintain the academic pace of an 8-week semester.

Several significant interactions were found among the faculty rank, school, and years of teaching variables. Regarding, if LSUS should continue to offer at least one or two class sections of each course in a face-to-face teaching format, a significant interaction existed between faculty rank and school, $\mathrm{F}(15,101)=1.890, \mathrm{R}^{2}=.359$. 
Post hoc t testing, however, later confirmed it not significant. Second, while both the survey items for keeping the traditional 16-week semester calendar, $\mathrm{F}(3,100)=2.745, \mathrm{R}^{2}=.344$, and teaching 300 , 400, 600, or 700 level compressed courses, $\mathrm{F}(13,105)=1.892, \mathrm{R}^{2}=.291$, were significant with interactions between faculty rank and years of teaching, Bonferroni did not verify. Regarding the difficulty of recruiting new faculty pending acceptance of compressed courses, analyses demonstrated several significant and close to significant interactions between years of teaching and school, $\mathrm{F}(15,101)=2.311, \mathrm{R}^{2}=.343$, but, again, none were confirmed by Bonferroni adjustment calculations.

The second part of the survey consisted of a check list allowing the faculty to make recommendations the university's administration regarding increasing student enrollment. Again, faculty could check up to five preferences each, but they were not asked to rank order their choices. As shown in table 3, the top five choices were pursuing partnerships with local companies $(n=54)$, increasing local advertisements $(n=54)$, creating new graduate programs $(n=49)$, establishing academic collaborations with regional high schools $(n=40)$, and introducing new undergraduate degree majors and programs $(n=39)$.

\subsection{Regression Analyses}

Survey questions previously found to be both significant and close to significant, $\mathrm{p} .06-.07$, underwent regression analyses. This amounted, first, to the significant questions, then the other questions close to significant. The remaining questions were excluded because they were neither significant nor close to significant during the initial analyses.

Other than a few exceptions, the regression analyses did not mimic what was found with the previous ANOVAs. Faculty age continued to be the only significant predictor for online 100 and 200 level elective courses, $\mathrm{F}(5,91)=$ $3.701, \mathrm{R}^{2}=.169$. Specifically, age was significant with $\mathrm{t}(96)=2.706$ and $\beta=.518$. Second, although previously significant, scheduling courses during the weekends as well as in the months of January, May, or August, was just close to significant during the regression analyses, $\mathrm{F}(5,89)=2.029, \mathrm{p}=.08, \mathrm{R}^{2}=.102$. Third, type of school was the only significant predictor, $\mathrm{t}(94)=-3.001, \beta=-.296$, for teaching 100 and 200 level elective compressed courses. Even though the regression analysis showed it as significant, $F(5,91)=3.375, \mathrm{R}^{2}=.156$, it was only close to significant during the initial ANOVA analysis. Regression analyses for the remaining questions were not significant with $\mathrm{p}$ values $\geq .10$.

\section{Discussion}

For the main question if faculty would support changing LSUS from a university with semester length courses to only online or compressed courses, opinion was opposed. This finding supports our first hypothesis or that most of the faculty will not favor the transition. This conclusion is based on several findings. First, all faculty, regardless of the demographics measured, strongly agreed that at least one or two class sections of each course should continue to be offered in a regular semester setting. Second, the additional mental and physical pressure stress associated with teaching compressed courses during the whole academic year, was a concern to most faculty. Third, faculty, particularly associate professors agreed that it would be more difficult to conduct research and provide service to the university if LSUS moves to teaching compressed courses. Fourth, faculty responded only partially to the survey items intended to spotlight the benefits of adopting compressed courses teaching schedules.

Another important finding was that faculty, based on age, began to show differences for teaching online and compressed courses. The youngest group was more willing to teach 100 and 200 level courses online than any of the other age groups. Although only close to significant, younger faculty also began to indicate a desire to teach 100 and 200 level compressed courses as well. In fact, as faculty member age increases, interest in teaching online and compressed courses decreases and erodes. This could signal a change in attitudes, at least, for online teaching such that younger faculty members, who were likely frequently used the Internet and computer technology during their formal education years are simply just more accepting of it than faculty members of an older generation. All faculty, however, started to change their responses when asked if they wanted to teach 300, 400, 600, and 700 (i.e., junior, senior, and graduate) level online and compressed courses. Faculty age means were moving from slightly agree towards to neutral when asked about teaching upper level online and compressed courses. Mean values increased because higher numbers for slightly disagree (4) and strongly disagree (5) rather than strongly agree (1) and slightly agree (2) were used for coding during the analyses. Perhaps, due to a lack of face-to-face interaction and time constraints, faculty thought academic standards may be lowered if junior, senior or graduate level courses are routinely taught online or compressed. 
How faculty, based on their respective ranks, responded to the survey is crucial for our second and third hypotheses. First, partial support was found for the second hypothesis. The seemingly herculean task of pursuing tenure and promotion while teaching online or compressed courses struck associate professors as more concerning than the non-tenure track instructors. This makes intuitive sense because instructors are not expected to conduct research, but it was surprising that the assistant professors did not side with the associate professors or react more to this survey item. The post hoc analyses were unable to distinguish assistant professors from any of the other faculty rank groups. Perhaps, the assistant professors were planning to satisfy the first few years of their academic research careers by publishing their dissertations or other past research conducted during graduate school. The third hypothesis also only generated partial support as well. While close to significant, associate professors, but not full professors, were more likely than adjuncts and instructors to think the average LSUS student will be unable to handle the academic pace of compressed courses for the whole four years as an undergraduate. We theorize that since associate professors generally teach academically higher level courses than adjuncts and instructors, they realize the difficulty of using a compressed format to present the material. Finally, associate professors more than instructors, who normally do not serve on faculty search committees, thought it may be more difficult to recruit new faculty if LSUS accepts only compressed course teaching.

Several possibilities exist as to why faculty do not want to teach, especially junior, senior, and graduate level, online and compressed university courses. First, faculty realize the complexity of university course material involved and think the average university student will succeed better by continuing with the traditional face-to-face 16-week semester format. Second, faculty have a number of other duties such as conducting research, sitting on university committees, and attending conferences. It will be difficult for faculty to fulfill their other university and community obligations if they must devote additional time to teaching online and compressed courses. Third, a number of the older faculty may not be comfortable with online courses and were concerned with the physical fatigue associated with teaching compressed courses. Finally, it will be a major economical gamble, to go into debt, to hire more faculty and staff while substantially changing the campus to accommodate the online and compressed learning only to have the significant increases in student enrollment never materialize.

While the research literature is mixed (Daniel, 2000; Davies, 2006; Scott \& Conrad, 1992), these findings do offer new insights. First, faculty opposition appears to remain an impediment to online and compressed teaching, but young faculty are willing to teach 100 and 200 level courses online. This could signal a change in attitudes of online teaching, such that younger faculty, who were possibly exposed more to the Internet and computers during their formal education years, are more accepting than older faculty. It was intriguing that no specific age group, however, expressed any real interest in teaching compressed courses. In addition, unlike Kretovics et al., (2005), no significant gender differences for compressed course teaching were found. Second, the data did not support Scott and Conrad's (1992) and Friedman's (1980) conclusions that social sciences and humanities faculty prefer traditional semester lengths courses. In this study, faculty from these schools favored minimester or month long courses. Furthermore, Humanities and Social Sciences faculty went on to support offering 300, 400, 600, and 700 compressed courses and were confident the students could handle the academic pace (Allen et al., 1982; Daniel, 2000). Third, the concern faculty all seem to share with being unable to devote enough time to research and university service during compressed teaching is still relevant (Scott and Conrad, 1992). Again, instructors, who are not tenure track, and professors, who likely have already attained the rank of full, did not express as much concern as the associate professors.

\subsection{Faculty Recommendations for Increasing Student Enrollment}

While the faculty did express concern with online and compressed teaching, they do recognize the importance of increasing student enrollment and are willing to compromise. First, faculty, in general, despite their demographics, slightly agreed that online and compressed courses will increase student enrollment. Second, the Schools of Human Sciences as well as Humanities and Social Sciences were more willing than the School of Business to teach courses during weekends or in the months of January, May, and August. Third, faculty from the School of Humanities and Social Sciences were more willing than Human Sciences to teach junior, senior, and graduate level compressed courses.

Our survey did give faculty the option to recommend which avenues they felt best the university could pursue to increase student enrollment should the online and compressed course proposals not be approved. The most frequent suggestions centered on LSUS becoming more of a fixture in the Shreveport-Bossier community. This would involve increasing local and regional advertisements so it becomes well known what LSUS has to offer. Next, partnerships with local companies, where perhaps employees may receive reduced tuition, and high schools, with students 
receiving early acceptance or financial aid counseling, garnered the second most number of votes. Finally, most of the faculty agreed that LSUS must offer more undergraduate and graduate majors. This may be more difficult for a commuter university than a private college because proposals for new majors must progress through a series of committees and state level approvals.

For those universities still pursuing a partial or full integration of online and compressed courses, the authors would like to make a number of suggestions. First, student services must be expanded. This ranges from hiring more faculty and staff in academic departments, technology support, registration, records, and financial aid to assist the new incoming student population. Second, for a university that offers only compressed courses, additional changes are required such as more classroom space and parking areas since most of the students will be on campus at the same time. Third, administrative officials should consider reducing the requirements for promotion and tenure so as to ease the burden on faculty members who will be devoting more of their time teaching online and compressed courses. Examples may include lowering the number of faculty research publications, offering more sabbaticals, or easing university service requirements. It will be increasingly difficult to maintain research programs when teaching compressed courses. Faculty members will be in the classroom 3-5 hours every day of the week. Fourth, conduct an extensive advertising campaign notifying the local area of the university's transition to online and compressed teaching.

\subsection{Study Limitation}

Close to half of the survey respondents were or above 58 years of age. This could be interpreted as possibly influencing some of the results, specifically teaching online courses. Faculty in their 50s and 60s, however, are still relevant because they constitute a large segment of the population. With the average age of tenured faculty now at 55, those in their 60s have doubled during the last decade (Fidelity Investments, 2013). In addition, more than half of all faculty, currently in their 50s and $60 \mathrm{~s}$, now claim they plan to either delay or not retire at all due to professional instead of financial reasons (Fidelity Investments, 2013).

\subsection{Future Research}

Regarding future research, three possible avenues warrant mention. First, the adoption of a pre and post-test format would be interesting. For example, faculty with little or no experience teaching online and compressed courses could take the survey, teach the courses, and then take the survey once again. The experience of teaching online and compressed courses may change the opinions of faculty who had earlier opposed such teaching formats. Second, faculty with previous experience teaching at community colleges either as graduate students or newly-minted $\mathrm{PhDs}$ may serve as another important group to survey. Most community colleges follow a heavy online and accelerated academic pace. Would faculty with this type of teaching experiences be more likely to support online and compressed teaching, even for junior, senior, or graduate level courses, than their colleagues who did not start their academic teaching careers at the community college level? Finally, could hybrid teaching be considered as a compromise for most faculty who are opposed to online and compressed courses? During hybrid teaching students will attend some face-to-face classes while relying on the Internet to take exams, submit assignments, and participate in discussions. Hybrid courses have been credited with the distinct advantage of giving students the flexibility of online aspects but still providing the desired face-to-face time with faculty members (Jackson \& Helms, 2008; Mansour \& Mupinga, 2007).

\section{Conclusions}

Current reductions in educational funding have forced universities and colleges to search for new ways to increase funding. Administrators from a number of universities and colleges have proposed offering considerably more online and compressed courses instead of those that are traditionally taught as a means to attract more students, but faculty input on such decisions must be considered. While the younger faculty members in our survey expressed interest in teaching lower level academic courses online, most of the faculty were opposed to switching the campus mainly to online or compressed teaching. In addition, associate professors agreed more than the other faculty groups that compressed course teaching will make it more difficult to recruit new faculty members and earn promotion to full professor. Although faculty do continue to express apprehension to teaching strictly online or compressed courses, there is also evidence they are open to compromise if it will benefit their universities and colleges in the future. 


\section{References}

Allen, I. E., \& Seamon, J. (2013). Changing course: Ten years of tracking online education in the United States (Babson Survey Research Group). Babson Park, MA.

Allen, J. L., Miller, T. A., Fisher, B., \& Moriarty, D. D. (1982). A survey of January interim psychology courses. Teaching of Psychology, 9, 230-231. http://dx.doi.org/10.1207/s15328023top0904_14

Arizona Board of Regents. (2011, January 14). ABOR responds to governor's fy12 budget recommendations [Media Release]. Retrieved from http://www.azregents.asu.edu/legislativeaffairs/newsreleases

Brett, M. (1996). Teaching extended class periods. Social Education, 60, 77-79.

Daniel, E. L. (2000). A review of time-shortened courses across disciplines. College Student Journal, 34, 298-308.

Davies, W. M. (2006). Intensive teaching formats: A review. Issues in Educational Research, 16, 1-21.

Dobbs, R., Ward, C., \& del Carmen, A. (2009). Students' perceptions of online courses: The effect of online course experience. The Quarterly Review of Distance Education, 10, 9-26.

Feldhaus, C. R., \& Fox, P. L. (2004). Effectiveness of an ethics course delivered in traditional and non-traditional formats. Science and Engineering Ethics, 10, 389-400. http://dx.doi.org/10.1007/s11948-004-0035-3

Fidelity Investments. (October, 2013). Higher education faculty study. Boston, MA.

Friedman, W. M. (1980). Class scheduling: Full-time students and faculty-an exploratory study. College Student Journal, 14, 341-346.

Jackson, M. J., \& Helms, M. H. (2008). Student perceptions of hybrid courses: Measuring and and interpreting quality. Journal of Education for Business, 84, 7-12. http://dx.doi.org/10.3200/JOEB.84.1.7-12

Kretovics, M. A., Crowe, A. R., \& Hyun, E. (2005). A study of faculty perceptions of summer compressed course teaching. Innovative Higher Education, 30, 37-51. http://dx.doi.org/10.1007/s10755-005-3295-1

Li, C., \& Irby, B. (2008). An overview of online education: Attractiveness, benefits, challenges, concerns, and recommendations. College Student Journal, 42, 449-458.

Maki, W., \& Maki, R. (2002). Multimedia comprehension skill predicts differential outcomes of web-based and lecture courses. Journal of Experimental Psychology, 8, 85-98. http://dx.doi.org/10.1037/1076-898x.8.2.85

Mansour, B. E., \& Mupinga, D. M. (2007). Students' positive and negative experiences in hybrid and online classes. College Student Journal, 41, 242-248.

Mitchell, M., Palacois, V., \& Leachman, M. (2014, May 1). States are still funding higher education below pre-recession levels. Center on Budget and Policy Priorities. Washington, DC.

Scott, P. A. (1995). Learning experiences in intensive and semester-length classes: Student voices and experiences. College Student Journal, 29, 207-213.

Scott, P. A. (1996). Attributes of high-quality intensive course learning experiences: Student voices and experiences. College Student Journal, 30, 69-77.

Scott, P. A., \& Conrad, C. F. (1992). A critique of intensive courses and an agenda for research. In J. C. Smart (Ed.), Higher education: Handbook of theory and research: Vol. 8 (pp. 411-459). NY: Agathon Press.

Seamon, M. (2004). Short and long-term differences in instructional effectiveness between intensive and $\begin{array}{lllll}\text { semester-length } \quad \text { courses. } & \text { Teachers }\end{array}$ http://dx.doi.org/10.1111/j.1467-9620.2004.00360.x

Stewart, C., Bachman, C., \& Johnson, R. (2010). Predictors of faculty and acceptance and online education. MERLOT: Journal of Online Learning and Teaching, 6, 597-616.

Ulmer, L. W., Watson, L. W., \& Derby, D. (2007). Perceptions of higher education faculty members on the value of distance education. The Quarterly Review of Distance Education, 8, 59-70.

Wilcoxson, L. (1998). The impact of academics' learning and teaching preferences on their teaching practices: A pilot study. Studies in Higher Education, 23, 59-61. http://dx.doi.org/10.1080/03075079812331380492 
Appendix

Faculty Survey

1. I would be interested in teaching LSUS's 100 and 200 level elective classes online.

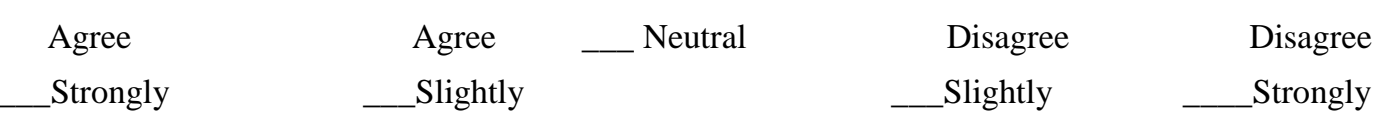

2. LSUS should continue to offer at least one or two sections of each class in a regular face-to-face teaching format.

3. I think we should teach LSUS's 300, 400, 600, or 700 level classes online.

4. I think LSUS should keep the traditional 16-week semester class calendar (spring and fall).

5. I would like for LSUS to offer courses during weekends and the months of January, May, or August,

6. I think it would be good if I could teach 100 and 200 level elective classes during an 8 -week semester session.

7. I would support teaching 300, 400, 600, or 700 level classes at LSUS during an 8-week semester session.

8. It will be challenging for me personally to teach 8-week semester courses year round.

9. It will be more difficult to recruit new faculty members if LSUS switches to an 8-week semester year round.

10. I think the majority of our students at LSUS will be able to keep up with the academic pace of an 8week semester.

11. Teaching classes in an 8-week semester format will make it more difficult to pursue tenure and promotion by publishing and service work to the university.

12. Being able to teach 3 courses during a one 8 -week semester and only one course the next session appeals to me.

13. I like the idea of teaching and finishing a two course sequence under just 16 weeks.

14. I think the 8-week semester plan will be helpful in recruiting new students to LSUS. 